\section{ACRL NOMINEES}

Candidates for ACRL offices in 1969 have been announced. They are:

Vice President and Presiment Elect

Anne C. Edmonds, Mount Holyoke College

Donald E. Thompson, Wabash College

DiREGTOR-AT-LARGE

Herbert Cahoon, Pierpont Morgan Library

Marcus A. McCorison, American Antiquarian

Society

Raymond A. Bohling, University of Minnesota

Mark M. Gormley, University of Wisconsin-

Milwaukee

Director on ALA Councul

Dorothy M. Drake, Scripps College

James F. Holly, Macalester College

David W. Heron, University of Nevada

Carl W. Hintz, University of Oregon

\section{ORIENTATION STUDY}

Library Orientation and Instruction: Verna V. Melum, who has been in charge of the library orientation and instruction program at Northern Illinois University for the past eleven years and before that at Stephens College, Columbia, Missouri, will take a sabbatical leave for the second semester of 1968-1969 to make a study of orientation and instruction programs in colleges and universities in various parts of the U.S. She will also be glad to serve as a consultant in this area, possibly in some high schools, too. Libraries which would like to have her visit them are invited to write her. Address: Parson Library, Northern Illinois University, DeKalb, Illinois 60115.

\section{DIRECTORY OF BOOK CATALOGS}

The Book Catalogs Committee of the Resources and Technical Services Division of ALA is compiling a directory of on-going book catalogs. Libraries who presently have book catalogs are asked to send their name and address as well as the name of the person responsible for the book catalog to Paula Kieffer, Coordinator, Technical Services, Baltimore County Public Library, 25 West Chesapeake Avenue, Towson, Maryland 21204.

1.

ACRL Membership Sept. 30, 1968

12,931

Sept. 30, 1967

12,226

Sept. 30, 1966

10,840

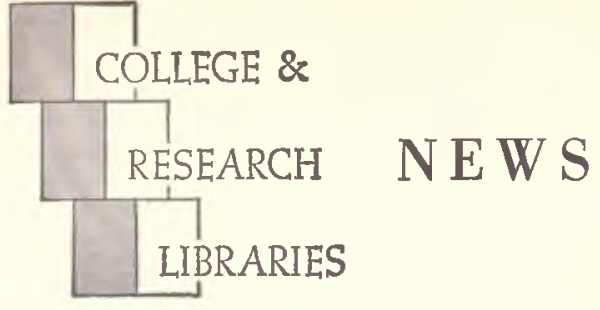

ACRL News Issue of College \& Research Libraries

Editor, David Kaser, Cornell University Libraries, Ithaca, N.Y. 14850.

Managing Editor, Mary Falvey, 50 E. Huron St., Chicago 60611.

News Editor, David Doerrer, Cornell University Libraries, Ithaca, N.Y. 14850.

Editorial Board: John M. DAwson, University of Delaware; Gustave A. Harrer, University of Florida; Samuel Rothstein, University of British Columbia; JAMES E. Skrppen, University of Califomia, Berkeley; Norman E. Tanis, Kansas State College of Pittsburg; Maurice F. Tauner, Columbia University; Eilees Thonnton, Oberlin College.

ACRL Officers, 1968/69: President, David Kaser; Chairman, College Libraries Section, Evan Ira Farber; Junior College Libraries Section, Shirley A. Edsall; Rare Books Section, J. M. Edelstein; Subject Specialists Section, Thomas D. Gillies; Agriculture and Biological Sciences Subsection, Louise Darling; Art Subsection, Herbert G. Scherer; Law and Political Science Subsection, Morris L. Cohen; Slavic and East European Subsection, Dmytro M. Shtohryn; University Libraries Section, G. F. Shepherd.

News from the Field, Personnel profiles and notes, classified advertising, official matter of ACRL, and other material of a timely nature is published in the News issues of College dr Research Libraries.

Inclusion of an article or advertisement in CRL does not constitute official endorsement by ACRL or ALA.

Production and Advertising and Circulation office: $\mathbf{5 0}$ E. Huron St., Chicago, Ill. 60611. Change of address and orders for subscriptions should be addressed to College of Research Libraries, for receipt at the above address, at least two months before the publication date of the effective issue.

Subscription to $C R L$ is included in membership dues to ACRL of $\$ 6$ or more; other subscriptions to $C R L$ are $\$ 10$ per year. Neither subscriptions nor memberships include miscellaneous unscheduled supplements, which are available by purchase only. Retroactive subscriptions are not accepted. Single journal copies are available at $\$ 1.50$ each and News issues at $\$ 1.00$ each from ALA Publishing Department.

Indexed in Library Literature. Abstracted in Library Science Abstracts. Book reviews indexed in Book Review Index.

College \& Research Libraries is the official journal of the Association of College and Research Libraries, division of the American Library Association; and is published seventeen times per year-bi-monthly as a technical journal with 11 monthly News jssues, combining July-August-at 1201-05 Bluff St., Fulton, Mo. 65251 .

Second-class postage paid at Fulton, Mo. 